\title{
Ensuring open access for publicly funded research
} (C) $($ (1) $(9)$ OPEN ACCESS

\author{
The right way to mix green and gold approaches
}

\author{
Peter Suber director of Harvard Open Access Project
}

Berkman Center for Internet and Society, Cambridge, MA 02138, USA

On 16 July 2012, three major announcements transformed open access policy in the United Kingdom. The Research Councils UK (RCUK) announced a stronger version of the open access policy it originally adopted in $2006 .{ }^{12}$ The UK minister of universities and science announced that the government had accepted most of the recent open access recommendations from the Working Group on Expanding Access to Published Research Findings that he appointed last September (informally called the Finch group after its convener, Janet Finch).$^{3-5}$ Finally, the Higher Education Funding Council for England (HEFCE) announced plans to require open access to research submitted to the next Research Excellence Framework in 2014. ${ }^{6}$

These announcements signal a massive shift towards open access for publicly funded research in the UK, which is extremely good for researchers and taxpayers. The question is whether the new approaches take full advantage of strategies developed over the past two decades for providing open access quickly and inexpensively. The most contentious issue is the balance between "green" and "gold" open access (box). ${ }^{7}$

The new RCUK policy requires open access for all RCUK funded research, starting next April, with a preference for gold over green. When authors publish in an open access journal, or a journal with an open access option, the journal must provide immediate open access to the published version under a CC-BY licence (box). When open access journals levy article processing charges, the RCUK is willing to pay them through block grants to universities. When authors publish in a journal without an open access option, their peer reviewed manuscript must become open access through a repository within six months of publication, or 12 months in the social sciences and humanities, under a CC-BY-NC licence (box).

The Finch group displays an even clearer preference for gold open access. The first Finch recommendation makes open access journals "the main vehicle" for publishing new research. The group recommends green open access only for theses and dissertations, grey literature, data, and preservation.

The Finch group expects the full transition to open access to cost $£ 50 \mathrm{~m}$ ( $€ 64 \mathrm{~m} ; \$ 78.5)$ to $£ 60 \mathrm{~m}$ a year, of which $£ 38 \mathrm{~m}$ a year would cover article processing charges. The rest would cover green open access infrastructure (that a 2011 report on which the Finch group itself often relies regards as "largely already . .. built"9) and renewed licences for journals that are not open access. Without a new allocation, these funds would come from the already tight budgets of funding agencies and universities.

Green open access is less expensive than gold open access and can easily accommodate the full research output of a university, funding agency, or nation. Just as importantly, green open access can be mandated today and gold cannot. Because only about $30 \%$ of the world's peer reviewed journals are open access, a policy requiring authors to publish in open access journals would limit their freedom to submit work to the journals of their choice. That could change if enough journals convert to open access, or enough adopt open access options, to become eligible for reimbursements for article processing charges from funders such as the RCUK. But gold open access isn't there yet.

Gold open access has separate advantages. Open access journals perform their own peer review, whereas open access repositories distribute articles that are peer reviewed elsewhere. Open access journals can generate revenue and even surpluses or profits. Such journals obtain permission to make their articles open access simply by making it a condition of publication. Open access repositories face a higher but surmountable hurdle here. They get their permissions contingently from rights holders who support open access, or systematically from open access policies at funding agencies and universities that secure permissions from authors before those authors sign publishing agreements. The RCUK and Finch groups, like most supporters of open access internationally, prefer immediate open access and open licences to delayed open access and all rights reserved copyrights. These benefits are easier to achieve with gold open access than with green, but green open access can achieve them too if funders and universities are prepared to demand them. The RCUK and Finch group ultimately prefer gold to green because they want these benefits now, not later, because UK funders are willing to pay for them, because publishers want revenue beyond subscriptions for providing them, and because publishers had a major role in the policy deliberations. 


\section{Definitions \\ Green open access: Delivered by repositories \\ Gold open access: Delivered by journals \\ CC-BY licence: Allows any kind of reuse provided the user makes proper attribution \\ CC-BY-NC licence: Similar to a CC-BY licence except that it does not allow commercial use}

The RCUK and Finch group take good advantage of the virtues of gold. The problem is that they fail to take good advantage of the virtues of green. The Wellcome Trust shows how to do the job better. The Wellcome Trust requires green open access for peer reviewed manuscripts arising from research that it has funded. If authors publish in open access journals with article processing charges, then the trust pays those fees and requires immediate open access under an open licence (soon to be CC-BY).${ }^{10}$ Like the RCUK and Finch group, the Wellcome Trust mixes green and gold, but it harnesses the power of green open access to assure open access for its full research output. A rapidly growing number of funding agencies and universities from around the world take the same step for the same reasons. The green part of the trust's larger open access policy may permit embargoes and omit open licences. But it is a fast and inexpensive first step to assuring free online access to research. That is a major advantage over the high access prices now shackling research, and that is the point. If we want to shorten embargoes and increase reuse rights, and we do, then we can take further steps, either by strengthening our green policies or paying for gold. What matters first is to use the tools we have to drive open access for the benefit of researchers and taxpayers.

To do that on a global scale, every research funding agency, public or private, and every university, should require green open access for new peer reviewed research articles by their grantees and faculty. Institutions should take that step before adding new incentives or new funding for gold. Because green and gold have complementary advantages, we eventually want both. But that means using the strengths of green, not just the strengths of gold, and the major strengths of green lie in providing a fast and inexpensive transition to free online access. To fund the transition to gold without first harnessing the power of green incurs premature expense, leaves the transition incomplete, and puts the interests of publishers ahead of the interests of research. That may be justified for publishers, but not for the non-profit funding agencies and universities devoted to advancing research.

A bill now before the US Congress, the Federal Research Public Access Act (FRPAA), ${ }^{11}$ would take that first green step for all the major funding agencies in the US federal government, expanding on the successful green open access mandate at the National Institutes of Health. On 17 July 2012, the day after the three big announcements in the UK, the European Commission announced a new open access policy for the European Union and recommended open access policies for member states. ${ }^{12} 13$ It is too early to tell how the European policies will balance green and gold. But the worldwide momentum for open access means that the UK needn't worry that it might be acting alone and making its own research freely available while continuing to pay for research from the rest of the world.

Competing interests: The author has completed the ICMJE uniform disclosure form at www.icmje.org/coi_disclosure.pdf (available on request from the corresponding author) and declares: no support from any organisation for the submitted work; no financial relationships with any organisations that might have an interest in the submitted work in the previous three years; PS works under grants and fellowships to advance the cause of open access but does not profit from the advance of open access.

Provenance and peer review: Commissioned; not externally peer reviewed.

Research Councils UK. RCUK announces new open access policy. 2012. www.rcuk.ac. uk/media/news/2012news/Pages/120716.aspx.

2 Research Councils UK. Research Councils UK's updated position statement on access to research outputs. 2006. http://web.archive.org/web/20060709230748/http://www.rcuk. ac.uk/access/2006statement pdf.

3 Department of Business Innovation and Skills. Government to open up publicly funded research. 2012. www.bis.gov.uk/news/topstories/2012/Jul/government-to-open-up-publiclyfunded-research.

4 Research Information Network. Finch report. 2012. www.researchinfonet.org/publish/finch/

$5 \quad$ Higher Education Funding Council for England. Working group on expanding access to published research findings. 2011. www.hefce.ac.uk/news/newsarchive/2011/name,62276, published
en.html.

6 Higher Education Funding Council for England. Impetus for open access in publicly funded research. 2012. www.hefce.ac.uk/news/newsarchive/2012/name,73613,en.html. Suber P. Open access. Sections 3.1 and 3.2. MIT Press, 2012.

8 Creative Commons. About the licenses. http://creativecommons.org/licenses/.

9 Gray C. Heading for the open road: costs and benefits of transitions in scholarly Gray C. Heading for the open road: costs and benefits of transitions in scholarly
communications. 2011. Research Information Network. www.rin.ac.uk/our-work/ communicating-and-disseminating-research/heading-open-road-costs-and-benefitstransitions-s.

10 Wellcome Trust. Wellcome Trust strengthens its open access policy. 2012. www.wellcome. ac.uk/News/Media-office/Press-releases/2012/WTVM055745.htm.

11 Notes on the Federal Research Public Access Act. Harvard Open Access Project, Berkman Center for Internet and Society,2012. http://cyber.law.harvard.edu/hoap/Notes_on_the_ Federal_Research_Public_Access_Act.

12 European Commission. Communication from the commission to the European parliament, the council, the European Economic and Social Committee and the Committee of the Regions. A reinforced European research area partnership for excellence and growth. 2012. http://ec.europa.eu/research/science-society/document_library/pdf_06/eracommunication-partnership-excellence-growth_en.pdf.

13 European Commission. Commission recommendation of 17.7 .2012 on access to and preservation of scientific information. 2012. http://ec.europa.eu/research/science-society/ document library/pdf_06/recommendation-access-and-preservation-scientific-information en.pdf.

\section{Cite this as: BMJ 2012;345:e5184}

This is an open-access article distributed under the terms of the Creative Commons Attribution Non-commercial License, which permits use, distribution, and reproduction in any medium, provided the original work is properly cited, the use is non commercial and is otherwise in compliance with the license. See: http://creativecommons.org/licenses/by$\mathrm{nc} / 2.0 /$ and http://creativecommons.org/licenses/by-nc/2.0/legalcode. 